\title{
Transatlantica
}

Revue d'études américaines. American Studies Journal

Couleurs d'Amérique

\section{Adrien Lherm. La culture américaine.}

Paris, Editions Le Cavalier Bleu, Idées reçues, 126 p., Novembre 2002.

\section{Anne Ollivier-Mellios}

\section{(2) OpenEdition}

Journals

Édition électronique

URL : http://journals.openedition.org/transatlantica/836

DOI : $10.4000 /$ transatlantica.836

ISSN : $1765-2766$

Éditeur

AFEA

\section{Référence électronique}

Anne Ollivier-Mellios, "Adrien Lherm. La culture américaine. », Transatlantica [En ligne], 1 | 2005, mis en ligne le 22 avril 2006, consulté le 29 avril 2021. URL : http://journals.openedition.org/transatlantica/ 836 ; DOI : https://doi.org/10.4000/transatlantica.836

Ce document a été généré automatiquement le 29 avril 2021

\section{cc)}

Transatlantica - Revue d'études américaines est mis à disposition selon les termes de la licence Creative Commons Attribution - Pas d'Utilisation Commerciale - Pas de Modification 4.0 International. 


\title{
Adrien Lherm. La culture américaine.
}

Paris, Editions Le Cavalier Bleu, Idées reçues, 126 p., Novembre 2002.

\author{
Anne Ollivier-Mellios
}

D'emblée, l'ouvrage pose à bon escient quelques questions essentielles sur le sens du mot culture et met en lumière la différence entre la Culture au sens à la fois plus philosophique et élitiste que lui donnent par exemple les Français et la culture, terme au sens plus large et quasi anthropologique utilisé plus communément dans les pays anglo-saxons et notamment aux Etats-Unis. Pour Adrien Lherm, la première ne peut exister sans la seconde. Il va même jusqu'à se demander dans l'introduction si Culture et culture ne sont pas une même réalité aux Etats-Unis. L'ouvrage est structuré en trois parties intitulées «culture vous avez dit culture?», «quelle culture?» et «une mosaïque de cultures ». Dans chacune des parties de courts chapitres passent en revue un certain nombre d'idées reçues sur la culture américaine. Sont notamment abordés les questions ayant trait à l'existence d'une culture aux Etats-Unis, son absence de passé, son impérialisme, sa superficialité, sa dépendance par rapport aux lois du marché, son pragmatisme, la standardisation, sa dimension plurielle. Chaque chapitre est l'occasion pour l'auteur de pointer les limites de ces idées reçues et de montrer comment la vision qu'ont les Français de la culture américaine, leur «mécompréhension » (plutôt qu'incompréhension) a pour origine leur méconnaissance de l'histoire américaine. Quelques exemples : si l'on s'étonne en France de l'absence d'un véritable magistère exercé par le gouvernement central en matière de culture, on comprend mieux cette configuration originale (d'une culture décentralisée où les initiatives privées et le mécénat jouent un rôle central) si l'on prend en compte l'histoire longue de ce modèle culturel dont les racines historiques remontent au temps de la réforme et l'inspiration renvoie aux pays d'Europe du Nord (p. 58). De même, les traditions (politiques et économiques) de ce côté-ci de l'Atlantique sont aux antipodes d'un système libéral américain dans lequel «la culture est une activité comme une autre qui ressortit au libre jeu des intérêts économiques ». Et A. Lherm de poursuivre : «ne relevant pas d'une quelconque exception, la culture américaine dépend de la logique terrestre des intérêts et son principe est celui du marché » (p. 61). On pourrait multiplier à l'infini ces exemples d'incompréhension réciproque qui trouvent leur source dans des traditions, philosophique (pragmatisme), religieuse, politique voire 
économique souvent très différentes. Parce qu'il est structuré autour de ces fameuses " idées reçues » qu'ont les Français de la culture américaine, l'ouvrage est d'un accès facile et renseigne très utilement le lecteur sur maint aspects de la civilisation/culture américaine.

Le parti pris de l'auteur semble avoir été d'éviter une approche historique chronologique afin, on l'a dit, de prendre comme point de départ de son analyse les «idées reçues ». On pourra peut être objecter que, ce choix, s'il ne gêne pas le lecteur averti, n'éclaire pas toujours suffisamment l'étudiant ou le lecteur en quête de repères historiques solides. On peut par exemple regretter que le rapport entre culture et grandes valeurs américaines ne soit abordé qu'à la page 59 ou que les rapports entre religion et culture soient évoqués à plusieurs reprises, forçant ainsi le lecteur à parfois revenir en arrière dans sa lecture (p. 18, p. 29, p. 85). On peut également se demander si l'une des particularités de cette culture américaine n'est pas d'avoir constamment réfléchi à son rapport à l'Europe, ainsi qu'au rapport entre culture dominante (mainstream) et contre culture ou culture contestataire. Cette auto réflexion de la culture (ou plus exactement des "producteurs culturels») me semble être l'apanage d'un pays qui, tout en ayant une culture jugée hégémonique par l'Europe, a toujours souffert (ou cru souffrir) d'un déficit culturel vis-à-vis de cette même Europe. Ce rapport complexe n'est guère évoqué dans l'ouvrage. Enfin, il semble qu'Adrien Lherm finisse par opter pour une définition très large de la culture américaine comme synonyme de civilisation américaine. Cette option présentée parmi d'autres dans l'introduction semble s'imposer dans les dernières pages de l'ouvrage, sans que l'auteur explique réellement ce qui l'a conduit à privilégier cette définition par rapport aux autres. Ces quelques remarques et interrogations sont bien la preuve qu'Adrien Lherm, par les thèmes qu'il aborde, stimule la réflexion de ses lecteurs. Au final, son ouvrage offre une synthèse très intéressante des différentes formes de culture américaine et quelques analyses particulièrement bien inspirées sur ces «différentes logiques sociales et nationales qui conduisent à des divergences d'appréciation sur la culture » de part et d'autre de l'Atlantique.

3 (Note : La liberté d'expression n'est pas garantie par le Deuxième amendement (p. 51) mais par le Premier. Steinbeck (p. 27) ne fait pas partie de la lost generation.)

\section{INDEX}

Thèmes : Recensions

\section{AUTEUR}

ANNE OLLIVIER-MELLIOS

Université Paris 12 